\title{
LA GRANDE FRESQUE DE LA VILLA DES MYSTÈRES À POMPÉI. MÉMOIRES D'UNE DÉVOTE DE DIONYSOS
}

\author{
Pedro Paulo FUNARI*
}

\begin{abstract}
SAURON, G. La Grande Fresque de la Villa des Mystères à Pompéi. Mémoires d'une dévote de Dionysos. Paris: Picard, 1998. 168 p., ISBN 2-7084-0545-4.
\end{abstract}

Gilles Sauron, professor de Arqueologia da Universidade da Borgonha, tem ministrado cursos de História da Arte Antiga na Escola Normal Superior, de Paris e, agora, publica esse exaustivo estudo monográfico sobre o famoso friso dionisíaco da Vila dos Mistérios de Pompéia. Seguindo uma lógica cartesiana, Sauron inicia com um capítulo sobre as questões relativas à interpretação do afresco e ao contexto histórico. Dioniso não era apenas o deus do vinho ou do teatro, mas representou a esperança de multidões de pessoas inquietas com o outro mundo e que celebravam seus mistérios com o fim de se identificar o seu glorioso destino. Em uma villa (casa de fazenda) de Pompéia, por volta de 80 a.C., rompia-se com a decoração tradicional, introduzindo um estilo em que as paredes se abriam para a ilusão de mundos imaginários. Sauron examina um século de pesquisas exegéticas sobre a pintura, a começar do escavador De Petra, em 1910, passando por Amedeo Maiuri, na década de 30, até chegar às variadas interpretações modernas, psicanalíticas ou mesmo laicas, como o fez, há pouco, Paul Veyne. Paul Zancker sintetizou, em meados da década de 90 , a noção de que seria melhor abandonar a busca de uma interpretação única e correta.

Sauron ressalta que os autores intelectuais da pintura procuraram ocultar e obscurecer seu significado, o que dificulta sua interpretação. Lembra, ainda, que também contribuiu para sua interpretação equivocada da

* Professor do Departamento de História - Unicamp. 
falsa, mas generalizada, idéia de que a arte romana fosse um simples empréstimo da tradição iconográfica grega. Parte, então, para um estudo pormenorizado do friso, a começar pelo par divino Dioniso e Sémele, segundo a proposta de Boyance, para o qual se representa mãe e filho, por oposição à visão mais corrente, que identifica um casal amoroso: Dioniso e Aridne. O que nos mostra, provavelmente, a pintura da Vila dos Mistérios é o retorno de Dioniso ao Olimpo, esgotado por uma noite agitada, para refugiar-se perto de sua mãe. Prevalece, pois, a deusa Sémele, o que se deve à identificação da sacerdotisa que encomendou a pintura com a mãe do deus. A imagem do par divino exalta a apoteose e a felicidade eterna de que se beneficiaram Dioniso e sua mãe Sémele, dois antigos heróis tornados deuses após experimentarem uma morte particularmente dramática (fulminada uma, desmembrado o outro) e a imagem dessas duas figuras divinas devia nutrir de esperança os homens e mulheres que buscavam, nas práticas rituais dos mistérios dionisíacos, uma resposta as suas interrogações sobre o destino no além-mundo.

A imagem de uma mulher na parede ocidental é identificada com a dona da casa, designada como domina. Esta aristocrata vizinha de Cícero fez-se representar com a dignidade matronal e a atitude meditativa e austera, a indicar um dionisismo filosófico e bem inserido nos valores romanos ( $m o s$ maiorum). Nas atividades humanas e religiosas de iniciada e iniciante, a domina pretendia seguir o caminho que poderia conduzir à sua própria divinização, a partir do modelo desses heróis dos tempos primordiais que, como Dioniso e Sémele, haviam podido escapar dos Infernos e chegar ao Olimpo. Como o friso foi concebido por uma mulher singular, a domina, e que, das duas divindades dispostas ao centro do friso, foi Sémele colocada no eixo de simetria da sala, Sauron sugere que a leitura desse documento deva começar pela parede direita, aquela que se refere à divinização de Sémele e a maneira como a domina reviveu as etapas decisivas do relato mítico na sua própria vida.

Evoca-se do casamento da domina e seu valor místico, pois a iniciação exigia como condição sine qua non o matrimônio (segundo o princípio ágamoi amýntoi, "os celibatários não são iniciados"). O primeiro rito consiste na representação de uma mulher com vestido violeta segurando um tirso diante de uma mênade nua, representação de Sémele como a primeira mênade, ou seja, como deusa prenhe do próprio Dioniso. O segundo rito 
inciático consiste na representação de Sémele a ser chicoteada, em imagem figurada de sua destruição por um raio, seguida da sacerdotisa que está a ponto de descobrir algo. Debaixo do véu, encontra-se o falo, representação do nascimento de Dioniso, deus da fecundidade. Em seguida, aparecem cenas com a domina enquanto educadora de seu filho, assimilado a Dioniso criança que aprende a leitura. Por fim, apresenta-se a morte de Dioniso e a participação da domina na iniciação masculina aos mistérios. Assim, a sucessão de cenas do afresco corresponde à cronologia do mito. Após a evocação da sua infância e paixão, Dioniso reaparece no Olimpo. A sucessão temporal rigorosa que preside à organização das cenas referem-se sempre ao mito, seja Sémele à direita, seja à divinização de Dioniso, à esquerda, não à vida da domina. Ela está representada nas etapas do ciclo mitológico, com referências, em cada momento, a sua própria vida de iniciada nos mistérios. Sauron propõe que a autora intelectual da pintura mandou executá-la, ao final da vida, como uma maneira de preparar-se para a morte.

$\mathrm{O}$ autor enfatiza que se trata de uma obra iconográfica original e única, feita para aquele ambiente e para aquela domina, para os aposentos privados da proprietária e, ao que tudo indica, por ela mesma planejada. Essa pintura de força expressiva excepcional resulta de seu caráter pessoal, da projeção da vida interior da domina, com sua memória, sentimentos, crenças e o que se exprime é, em última instância, a convicção íntima dessa mulher de poder participar da eternidade e da felicidade da vida dos deuses.

Diversos são os pontos inovadores nessa obra de Sauron. Em primeiro lugar, mostra como conceitos de arte modernos, oriundos do Renascimento, são inadequados para o estudo da arte antiga, pois havia uma total disjunção entre o executor, simples artesão e o autor intelectual da composição. Em segundo lugar, a leitura pormenorizada das paredes mostra que a composição, original, nunca poderia ser baseada em exemplos gregos, o que está a demonstrar tanto a autonomia criativa romana, como a ligação, fecunda mas não servil, da arte romana com a grega e a helenística. Em terceiro lugar, ao propor uma autoria feminina para a composição, Sauron rompe com aquelas concepções que excluem do campo das possibilidades interpretativas a ação feminina no mundo antigo, como se a misoginia de alguns autores clássicos bastasse para justificar tal atitude por parte dos estudiosos modernos. Em quarto lugar, mas não menos importante, o autor relaciona as inquietações íntimas de uma aristocrata de fins da República 
Romana com o contexto histórico que estava a indicar uma crescente preocupação com a morte.

As propostas interpretativas de Sauron, ainda que sempre muito bem documentadas, tanto por meio de citações de autores antigos, como, principalmente, por outras representações figuradas, não constituem provas. Uma pintura parietal tão cheia de imagens de difícil e ambígua interpretação não poderia ocorrer de outra maneira. Contudo, o seu mérito maior consiste em mostrar como, ao desafiar-se os discursos interpretativos tradicionais, o estudioso pode encontrar lógicas mais coerentes e menos presas aos nossos próprios preconceitos e esquemas acadêmicos consolidados. Seria mesmo uma mulher a autora intelectual do friso? Seria mesmo uma criação original romana? O que se pode dizer é que essas hipóteses inovadoras, após a leitura do volume, parecem menos limitadas do que as tradicionais. Essa atitude crítica, além de todos os méritos já mencionados, recomenda a leitura dessa obra. 